\title{
THE IMPACT OF THE TAIPEI PORT CONTAINER TERMINAL ON THE NORTHERN REGION OF TAIWAN: A COMPUTABLE GENERAL EQUILIBRIUM MODEL
}

\author{
Wen-Sheng Chen \\ Department of Business Administration National Kaohsiung University of Applied Sciences; Department of Resources \\ Engineering, National Cheng Kung University, Taiwan, R.O.C. \\ Chia-Yon Chen \\ Department of Resources Engineering, National Cheng Kung University, Taiwan, R.O.C. \\ Feng-Chin Chen \\ Department of Innovation Management, Aletheia University, Taiwan, R.O.C., fcchen@mt.au.edu.tw \\ Chun-Chu Liu \\ Department of International Business, Chang Jung Christian University, Taiwan, R.O.C.
}

Follow this and additional works at: https://jmstt.ntou.edu.tw/journal

Part of the Engineering Commons

\footnotetext{
Recommended Citation

Chen, Wen-Sheng; Chen, Chia-Yon; Chen, Feng-Chin; and Liu, Chun-Chu (2011) "THE IMPACT OF THE TAIPEI PORT CONTAINER TERMINAL ON THE NORTHERN REGION OF TAIWAN: A COMPUTABLE GENERAL EQUILIBRIUM MODEL," Journal of Marine Science and Technology. Vol. 19: Iss. 2, Article 2.

DOI: $10.51400 / 2709-6998.2145$

Available at: https://jmstt.ntou.edu.tw/journal/vol19/iss2/2

This Research Article is brought to you for free and open access by Journal of Marine Science and Technology. It has been accepted for inclusion in Journal of Marine Science and Technology by an authorized editor of Journal of Marine Science and Technology.
} 


\title{
THE IMPACT OF THE TAIPEI PORT CONTAINER TERMINAL ON THE NORTHERN REGION OF TAIWAN: A COMPUTABLE GENERAL EQUILIBRIUM MODEL
}

\author{
Wen-Sheng Chen*, Chia-Yon Chen**, Feng-Chin Chen***, and Chun-Chu Liu****
}

Key words: computable general equilibrium, social accounting matrix.

\begin{abstract}
There are some primary modelling tools, including econometric forecasting models, fixed price input-output (I-O) multi-sector models, social accounting matrix (SAM) and computable general equilibrium (CGE) models, used to analyse regional economic issues. CGE models combine the advantages of econometric, I-O models and SAM, strengthening the theoretical basis of the modelling effort and thus enabling more precise policy analysis. Current CGE literature includes models used to analyse international trade, tax reform, energy and environment issues. However, application of this technique on a regional scale is rare in the scientific literature. In this paper, a small regional computable general equilibrium model is constructed and applied to analyse the economic impact of constructing Taipei Port Container Terminal (TPCT) locating in northern Taiwan. The research results provide a valuable reference for decision-makers in formulating ocean shipping and regional policies, as well as helping business managers with strategic planning.
\end{abstract}

\section{INTRODUCTION}

Impact analysis can be defined as an assessment of change in overall economic activity as a rule of some special change in one or several economic activities [21]. Impact analysis in a

Paper submitted 05/19/09; revised 10/23/09; accepted 11/12/09. Author for correspondence: Feng-Chin Chen (e-mail:fcchen@mt.au.edu.tw).

*Department of Business Administration National Kaohsiung University of Applied Sciences; Department of Resources Engineering, National Cheng Kung University, Taiwan, R.O.C.

**Department of Resources Engineering, National Cheng Kung University, Taiwan, R.O.C.

***Department of Innovation Management, Aletheia University, Taiwan, R.O.C.

****Department of International Business, Chang Jung Christian University, Taiwan, R.O.C. region focuses on interaction between economic policy changes and the implications of these changes for the local economy. In particular, it may reflect local or national concern about the effect of change on a variety of actors or agents within the local economy, such as specific socioeconomic groups, specific sectors, or specific locations. Changes in the level and distribution of local employment, income, sales, and wealth are often the target of analysts in the context of regional planning [38].

There are several tools available to the analyst to assess regional impacts of programmes. For example, partial equilibrium models (export-base models, benefit-cost analysis and econometric models) and general equilibrium models (I-O model, SAM model, and CGE model) may be used. Partial equilibrium models are limited in their analytical approach because they often focus on specific sectors, thus ignoring the larger economy-wide effects. Unlike partial equilibrium models, general equilibrium models account for the interindustry linkages in an economy and is viewed as a more appropriate framework for conducting economic impact analysis. General equilibrium models can be categorized into fixed-price models (I-O models and SAM models) and flexible price modes (CGE models). It is critical to the relative accuracy of estimates from the above two general equilibrium models. Fixed-price I-O models and SAM models provide an internally consistent representation of regional economic structure. However, this consistency is arguably more realistic and explicit in CGE than in either I-O or SAM.

CGE analysis has been applied to a wide range of policy issues, which include, among others, income distribution [17, 42], trade policy [4, 5, 20, 41], development strategy [1], taxes, long-term growth and structural change [10, 31]. However, most computable general equilibrium models have been used to capture the effects of policies and economic shocks at the national level. Recently, CGE models have been proposed as an alternative analytical tool for policy analysis on a regional scale $[2,18,19,22,23,25-29,34-36]$.

In Taiwan, I-O models are the most common application of general equilibrium techniques used for regional economic impact analysis. Relatively few CGE models have been de- 
veloped in the Taiwan context $[8,26,43]$. Even fewer have been devoted to enquiring about the economic impact of local important investment on a small regional scale in Taiwan. This study attempts to fill this gap by developing a CGE model of the north Taiwan regional economy. CGE models allow for more flexibility and are more consistent with neoclassical economic theory and, thus, may generate less biased estimates when compared with other modelling techniques [39]. The CGE approach permits prices of inputs to vary with respect to changes in output prices and, thus, allows one to capture the behaviour of economic agents. It incorporates a variety of flexible production functions that allow producers to substitute cheaper inputs for more expensive inputs. This approach can also accommodate constraints on the availability of primary inputs and accounts for additional intersectoral linkages. For example, if factors of production are limited in supply, the expansion in some sectors will draw factors of production from other sectors thereby causing a contraction in those industries.

CGE models have been proposed as an alternative analytical tool for policy analysis on a regional scale and are the focus of this paper. Seung et al. (2000) contend that a regional CGE model is more theoretically grounded than supplydetermined I-O models for impact analysis, where the productive capacity of sectors is reduced in a regional economy. They conclude that although supply-determined or mixed endogenous-exogenous SAM models are appropriate for addressing income distribution issues and are relatively easy to implement, they suffer from limited flexibility by assuming fixed prices and ignoring substitution effects in production and consumption. CGE models provide the flexibility necessary for improving analysis of a regional economy by overcoming the restrictive assumptions contained in I-O and SAM models. In a CGE model, prices adjust to clear markets of outputs and factors of production.

The organization of the paper is as follows. In the next section the computable general equilibrium model is briefly described. Thereafter, the data sources and simulation results are presented and discussed. The final section gives a summary and conclusions.

\section{MODEL FORMULATION}

In recent years, a growing number of researchers have begun to use the computable general equilibrium models to analyse the impacts of regional policies. Therefore, in analysing the impacts of constructing TPCT locating in northern Taiwan, a computable general equilibrium approach is generally considered an appropriate tool. In the northern Taiwan CGE (NTCGE) model, there are two economic regions, northern Taiwan and the rest of the world, which includes Taiwan and all other countries. Economic agents operating in the two regions consist of producers, private households, local government and central government.

The computable general equilibrium model used is a static model, which follows closely the Dervis et al. (1982) tradition. Modifications include alternative function forms for production technology and disaggregate household groups. In the computable general equilibrium model, the Taiwan economy is divided into 14 sectors: (1) agriculture (i.e. agriculture, forestry and fishing), (2) mining, (3) processed food, (4) other chemical products, (5) petroleum refineries, (6) iron and steel, (7) electrical and electronic machinery, (8) precision instruments, (9) other manufacturing, (10) construction, (11) electricity, gas and water (12) transport, (13) trade and eatingdrinking places, and (14) finance, services and others. Five equal divisions of household are specified, using the classifications from The Report on the Survey of Family Income and Expenditure in Taiwan Area [12]. A disaggregate social accounting matrix given in Table 1 is designed to reflect the circular flow of the northern Taiwan economy that is embodied in northern Taiwan's computable general equilibrium model is outlined below. The model is composed of production and factor markets, expenditure and income, foreign exchange market, prices, market equilibrium and macro close rule. The following paragraphs provide a general description of northern Taiwan's computable general equilibrium model. The production process is assumed to be a two- stage process. In the first stage, producers select optimal quantities of capital and labor, using a Cobb-Douglas (C-D) production function [39]. In the second stage, firms choose intermediate inputs in combination with primary inputs using a fixed-proportion Leontief production technology. Other production technologies may be used at this stage. However, in most regional applications, the Leontief production technology is the preferred choice [32]. Factor demands are derived from first-order conditions, using a conventional profit maximization approach. Labor and capital factors are perfectly mobile between economic sectors and are fully employed in the base year. The model has five household groups; for each household group there is a representative consumer who determines his consumption behavior from utility maximization. The consumer preferences are characterized by a Cobb-Douglas utility function for each representative consumer; this allows for different marginal budget shares for the five household groups. The household budget account constitutes income revenue and expenditure. The main sources of household income revenue include labor income, distributed profits, government transfer and net transfer from abroad. Each household expenditure is allocated to private consumption, direct taxes and private saving. The two levels of government accounted for in the model are local and central government. Government actions have a significant influence on the economy through its income revenue and spending changes. The main sources of government revenues include indirect taxes, tariffs, enterprise taxes and direct taxes. Government spending constitutes government consumption, transfer to enterprise, transfer to household and government saving. Our model assumes government income revenue equal to income spending. The enterprise in this model includes private companies, public companies and 
Table 1. Structure of a social accounting matrix for Northern region in Taiwan.

2004 (million NT)

\begin{tabular}{|c|c|c|c|c|c|c|c|c|c|}
\hline \multirow[b]{3}{*}{ Receipts } & \multirow{2}{*}{\multicolumn{4}{|c|}{ Expenditures }} & \multirow{2}{*}{\multicolumn{3}{|c|}{ Institutions }} & & \multirow[b]{3}{*}{ Rest of world } \\
\hline & & & & & & & & & \\
\hline & Activities & Commodities & Labor & Capital & Enterprises & Households & Government & & \\
\hline Activities & & $\begin{array}{c}\text { Domestic sales } \\
8,041,768\end{array}$ & & & & & & & $\begin{array}{c}\text { Exports } \\
1,865,508\end{array}$ \\
\hline Commodities & $\begin{array}{l}\text { Intermediate } \\
\text { inputs } \\
5,810,828\end{array}$ & & & & & $\begin{array}{c}\text { Private } \\
\text { consumption } \\
2,551,468\end{array}$ & $\begin{array}{c}\text { Government } \\
\text { consumption } \\
566,708\end{array}$ & $\begin{array}{l}\text { Investment } \\
972,654\end{array}$ & \\
\hline \multicolumn{10}{|l|}{ Factors } \\
\hline Labor & $\begin{array}{c}\text { Wages } \\
2,093,400\end{array}$ & & & & & & & & $\begin{array}{l}\text { Net labor income } \\
\text { from abroad }-9,174\end{array}$ \\
\hline Capital & $\begin{array}{c}\text { Rentals } \\
1,383,508\end{array}$ & & & & & & & & $\begin{array}{l}\text { Net capital income } \\
\text { from abroad } 20,466\end{array}$ \\
\hline \multicolumn{10}{|l|}{ Institutions } \\
\hline Enterprises & & & & $\begin{array}{c}\text { Capital } \\
\text { income } \\
1,403,974\end{array}$ & & $\begin{array}{c}\text { Government } \\
\text { transfers } \\
107,824\end{array}$ & & & \\
\hline Households & & & $\begin{array}{c}\text { Labor } \\
\text { Income } \\
2,084,226\end{array}$ & & $\begin{array}{c}\text { Distributed } \\
\text { profits } \\
1,161,362\end{array}$ & $\begin{array}{c}\text { Household } \\
\text { transfer } \\
93,218\end{array}$ & $\begin{array}{c}\text { Government } \\
\text { transfers } \\
14,606\end{array}$ & & $\begin{array}{l}\text { Net transfer from } \\
\text { abroad } 62,398\end{array}$ \\
\hline Government & $\begin{array}{c}\text { Indirect } \\
\text { taxes } \\
216,838\end{array}$ & $\begin{array}{l}\text { Tariffs } \\
40,932\end{array}$ & & & $\begin{array}{c}\text { Enterprise } \\
\text { taxe } \\
159,674\end{array}$ & $\begin{array}{c}\text { Direct } \\
\text { taxes } \\
270,362\end{array}$ & & & $\begin{array}{l}\text { Net transfer from } \\
\quad \text { abroad } 280\end{array}$ \\
\hline $\begin{array}{l}\text { Capital } \\
\text { account }\end{array}$ & $\begin{array}{c}\text { Capital } \\
\text { depreciation } \\
402,702\end{array}$ & & & & $\begin{array}{c}\text { Retained } \\
\text { earnings } \\
190,762\end{array}$ & $\begin{array}{c}\text { Private } \\
\text { saving } \\
461,784\end{array}$ & $\begin{array}{c}\text { Government } \\
\text { saving } \\
-2,050\end{array}$ & & $\begin{array}{l}\text { Net foreign } \\
\text { borrowing } \\
-80,544\end{array}$ \\
\hline Rest of world & & Imports & & & & $\begin{array}{l}\text { Foreign } \\
\text { transfer }\end{array}$ & $\begin{array}{l}\text { Foreign } \\
\text { transfer }\end{array}$ & & \\
\hline & & $1,818,958$ & & & & 38,978 & 998 & & \\
\hline
\end{tabular}

Source: DGBAS (2004).

nonprofit enterprise, using the aggregate catalogue of National Income in Taiwan Area [12]. The main sources of enterprise revenues include capital income, government transfer and net transfer from abroad. Main enterprise outlays include distributed profits, enterprise taxes and retained earnings. It is also assumed that enterprise income revenues equal to outlays. In this model, small-open-economy assumptions are made, implying that northern Taiwan cannot affect world price with its exports and imports. The model assumes a floating exchange rate mechanism and contains a balance-of-trade constraint. The value of total exports includes export trade, net labor income from abroad, net capital income from abroad, net transfer from abroad to enterprise and net transfer from abroad to household. The value of total imports consists of import trade and net foreign borrowing. The model assumes imperfect substitution between imports and domestic goods, using the Armington constant elasticity of substitution function form [3]. Thus, the import demand for a specific sector becomes derived demand. On the export side, the export demand for a specific commodity depends on the world price of exported goods measured in foreign exchange units relative to the price level of domestic goods. In a market equilibrium condition, we assume that the total supply of commodities equals the total demand for commodities. As stated previously, total supply of composite commodities is a CES combination of domestic goods and imports. Total demand consists of intermediate inputs, private consumption, government consumption and investment. Finally, according to Rickman (1992), the results of neoclassical closure in a regional context often are more consistent with econometric models. Hence, the neoclassical closure is adapted in the NTCGE. In the computable general equilibrium model, the system can only determine relative prices, and solve for prices relative to a numeraire. Because the NTCGE is a regional model, the exchange rate is used as the numeraire good, following Sullivan et al. (1997).

\section{REGION, DATA SOURCES, CALIBRATION, AND ELASTICITY SPECIFICATION}

The northern region of Taiwan is composed of seven distinct counties or cities: Taipei city, Taipei county, Keelung city, Taoyuan County, Hsinchu city, Hsinchu county, and Yilan County. This model is calibrated for the 2004 base year data set. The data on the Taiwan economy are organized into a 
Table 2. Simulation of regional output, export, import at TPCT construction phase.

\begin{tabular}{|c|c|c|c|c|c|c|c|c|c|}
\hline \multirow{2}{*}{ sector } & \multicolumn{3}{|c|}{ output } & \multicolumn{3}{|c|}{ export } & \multicolumn{3}{|c|}{ import } \\
\hline & base & Simulation & $\pm \%$ & base & Simulation & $\pm \%$ & base & Simulation & $\pm \%$ \\
\hline agriculture & 60,227 & 60,293 & 0.11 & 26,326 & 26,470 & 0.55 & 19,923 & 19,972 & 0.25 \\
\hline mining & 36,708 & 35,717 & 2.70 & 4,980 & 4,914 & 1.31 & 25,570 & 25,358 & 0.83 \\
\hline processed food & 26,258 & 24,216 & 3.26 & 19,675 & 19,350 & 1.65 & 18,334 & 18,196 & 0.75 \\
\hline other chemical products & 421,052 & 422,820 & 0.42 & 214,504 & 215,319 & 0.38 & 104,936 & 105,198 & 0.25 \\
\hline Petroleum refineries & 803,642 & 819,956 & 2.03 & 212,491 & 213,050 & 2.63 & 144,376 & 144,669 & 2.03 \\
\hline iron and steel & 94,948 & 109,238 & 15.05 & 24,938 & 29,115 & 16.75 & 165,882 & 180,977 & 9.10 \\
\hline electronics and relatives & 963,496 & $1,019,378$ & 5.80 & 740,530 & 788,738 & 6.51 & 260,896 & 272,245 & 4.35 \\
\hline Precision machinery & 592,656 & 598,701 & 1.02 & 388,960 & 392,655 & 0.95 & 138,020 & 139,055 & 0.75 \\
\hline other manufacturing & $2,173,108$ & $2,070,102$ & 4.74 & 660,640 & 634,941 & 3.89 & 178,670 & 171,362 & 4.09 \\
\hline construction, civil engineering & 717,508 & 838,408 & 16.85 & 63,804 & 74,797 & 17.23 & 21,048 & 24,190 & 14.93 \\
\hline electricity, gas and water & 328,748 & 340,517 & 3.58 & 17,974 & 18,564 & 3.28 & 792 & 807 & 1.91 \\
\hline transportation & 482,126 & 504,159 & 4.57 & 82,910 & 86,392 & 4.20 & 100,512 & 103,457 & 2.93 \\
\hline Wholesale, retail, and food services & 970,586 & $1,034,159$ & 6.55 & 258,178 & 269,021 & 6.38 & 182,110 & 189,758 & 4.20 \\
\hline finance, services and others & $2,236,210$ & $2,305,533$ & 3.10 & 89,600 & 92,306 & 3.02 & 557,886 & 574,623 & 3.00 \\
\hline
\end{tabular}

social accounting matrix. A disaggregate social accounting matrix combines the input-output table [12] with the national income accounting. Therefore, disaggregate social accounting matrix is based on the national income accounting, and input-output data is adjusted for consistency. In addition to the data in the input-output table and national income accounting, the database for our computable general equilibrium model includes labor, capital, income distribution matrix, various elasticities, and other parameters. The labor and capital data are from the Year Book of Manpower Statistics [12] and Trends in Multifactor Productivity [12]. A multi-sector income distribution matrix is transformed income flows between industry and the five equal divisions of household. This matrix is from The Report of Survey of Family Income and Expenditure [12]. In order to model production technology, composite commodities and the export demand function, we need a variety of elasticities. Elasticities of production technology are constructed on the basis of the elasticities used in Burniaux et al. (1992) and Lin (1998). Following Chu (1996) we set the elasticity between domestic and imported goods and elasticity of export demand function. Calibrating against a benchmark equilibrium data set derived from the above considerations numerically specifies other parameters in this model. Simulation results are generated using the GAMS program [6].

\section{RESULTS}

Analysing the impact of the establishment of TPCT on the northern region in Taiwan's economy is performed in two stages. The first stage simulates the economic impact of the TPCT construction phase. The second looks at the economy of the TPCT when it is up and running. The construction planning of TPCT is to be implemented in two stages: the first stage was from May 2003 to December 2008, and the development area was 31.6 hectares; the second stage runs from January 2009 to December 2014 with a further 79.3 hectares of development area. The total area developed covers 110.9 hectares. The anticipated construction cost of TPCT is 20.315 billion NT dollars, and the majority of the cost is in planning application fees, construction costs, and maintenance and operation costs. It is estimated the sales by TPCT in 2009 will reach 1021 million NT dollars, and 5238 million NT dollars by 2014. Scenario 1, showing at the Tables 2-4, output effects reveal that the most impacted industries in northern Taiwan are iron and steel, civil engineering, other manufacturing industries, and service industries, which account for $28 \%$ of the total output variation in northern Taiwan. Industries having the strongest employment effects in northern Taiwan are the iron and steel industry, civil engineering, other manufacturing industries, wholesale and retail industry, and the food service industry, which claim $36 \%$ of the total employment effect in northern Taiwan. The industries having the greatest income effects in northern Taiwan are the iron and steel industry, other manufacturing industry, and the service industry, which explains $33 \%$ of total income effect in northern Taiwan.

Scenario 2, revealing in the Tables 5-6, output effects reveal that the export-oriented industries, which are induced and facilitated by TPCT for cargo shipping, having the largest output effect in northern Taiwan are the electronics and mechanical equipment manufacturing industry (IC, computers and peripheral equipment $\mathrm{Mfg}$, logistics and telecommunications), precision machinery manufacturing industry, and the iron and steel industry, which account for $73 \%$ of the total output effect in northern Taiwan. Employment effects in northern Taiwan are mainly observed in the electronics and mechanical equipment manufacturing industry (IC, computer 
Table 3. Simulation of investment impact on employment, wages at TPCT construct phase.

(million NT)

\begin{tabular}{|c|r|r|r|r|r|r|}
\hline \multirow{2}{*}{ sector } & \multicolumn{3}{|c|}{ employment } & \multicolumn{3}{c|}{ wages } \\
\cline { 2 - 7 } & \multicolumn{1}{|c|}{ base } & Simulation & $\pm \%$ & \multicolumn{1}{c|}{ base } & Simulation & $\pm \%$ \\
\hline agriculture & 507,362 & 508,072 & 0.14 & 114,724 & 114,322 & -0.35 \\
\hline mining & 22,352 & 21,748 & -2.70 & 8,234 & 7,961 & -3.31 \\
\hline processed food & 84,700 & 81,939 & -3.26 & 33,860 & 32,624 & -3.65 \\
\hline other chemical products & 60,342 & 60,203 & -0.23 & 21,144 & 21,017 & -0.60 \\
\hline petroleum refineries & 5,138 & 5,251 & 2.20 & 5,250 & 5,299 & 0.93 \\
\hline iron and steel & 24,336 & 28,047 & 15.25 & 13,482 & 15,336 & 13.75 \\
\hline electronics and relatives & 44,300 & 45,540 & 2.80 & 15,924 & 16,235 & 1.95 \\
\hline precision machinery & 195,082 & 195,901 & 0.42 & 53,994 & 53,702 & -0.54 \\
\hline other manufacturing & $1,013,622$ & 925,031 & -8.74 & 450,940 & 407,695 & -9.59 \\
\hline construction, civil engineering & 314,886 & 371,093 & 17.85 & 120,834 & 154,945 & 28.23 \\
\hline electricity, gas and water & 26,616 & 27,393 & 2.92 & 25,446 & 26,011 & 2.22 \\
\hline transportation & 249,628 & 256,043 & 2.57 & 125,214 & 127,743 & 2.02 \\
\hline wholesale, retail, and food services & 893,034 & 912,234 & 2.15 & 273,824 & 279,656 & 2.13 \\
\hline finance, services and others & $1,773,856$ & $1,835,941$ & 3.50 & 830,526 & 858,930 & 3.42 \\
\hline
\end{tabular}

Table 4. Simulation of regional economic impact at TPCT construction phase.

\begin{tabular}{|c|r|r|r|}
\hline \multicolumn{1}{|c|}{ (million NT) } \\
\hline Regional GDP & base & simulation & $\pm \%$ \\
\hline +consumption & $2,551,468$ & $2,577,493$ & 1.02 \\
\hline+ investment & 972,654 & 992,593 & 2.05 \\
\hline+ government & 566,708 & 629,896 & 11.15 \\
\hline +export & $1,865,508$ & $1,791,820$ & -3.95 \\
\hline -import & $1,818,958$ & $1,943,557$ & 6.85 \\
\hline total & $4,137,380$ & $4,048,245$ & -2.29 \\
\hline
\end{tabular}

Table 5. Simulation of regional output, export, import at TPCT operation phase.

\begin{tabular}{|c|c|c|c|c|c|c|c|c|c|}
\hline \multirow{2}{*}{ Sector } & \multicolumn{3}{|c|}{ output } & \multicolumn{3}{|c|}{ export } & \multicolumn{3}{|c|}{ import } \\
\hline & base & Simulation & $\pm \%$ & base & Simulation & $\pm \%$ & base & Simulation & $\pm \%$ \\
\hline agriculture & 60,227 & 60,588 & 0.60 & 26,326 & 26,468 & 0.54 & 19,923 & 20,046 & 0.62 \\
\hline mining & 36,708 & 35,897 & -2.21 & 4,980 & 4,970 & -0.20 & 25,570 & 25,621 & 0.20 \\
\hline processed food & 26,258 & 25,436 & -3.13 & 19,675 & 18,893 & -3.97 & 18,334 & 17,769 & -3.08 \\
\hline other chemical products & 421,052 & 452,126 & 7.38 & 214,504 & 229,755 & 7.11 & 104,936 & 112,586 & 7.29 \\
\hline petroleum refineries & 803,642 & 853,629 & 6.22 & 212,491 & 224,454 & 5.63 & 144,376 & 153,515 & 6.33 \\
\hline iron and steel & 94,948 & 100,379 & 5.72 & 24,938 & 26,357 & 5.69 & 165,882 & 175,254 & 5.65 \\
\hline electronics and relatives & 963,496 & $1,055,992$ & 9.60 & 740,530 & 808,288 & 9.15 & 260,896 & 283,724 & 8.75 \\
\hline precision machinery & 592,656 & 645,699 & 8.95 & 388,960 & 422,994 & 8.75 & 138,020 & 149,958 & 8.65 \\
\hline other manufacturing & $2,173,108$ & $2,046,850$ & -5.81 & 660,640 & 625,295 & -5.35 & 178,670 & 172,327 & -3.55 \\
\hline construction, civil engineering & 717,508 & 692,395 & -3.50 & 63,804 & 61,539 & -3.55 & 21,048 & 20,391 & -3.12 \\
\hline electricity, gas and water & 328,748 & 336,967 & 2.50 & 17,974 & 18,384 & 2.28 & 792 & 811 & 2.45 \\
\hline transportation & 482,126 & 529,615 & 9.85 & 82,910 & 90,728 & 9.43 & 100,512 & 110,119 & 9.56 \\
\hline wholesale, retail and food services & 970,586 & $1,028,627$ & 5.98 & 258,178 & 272,765 & 5.65 & 182,110 & 191,852 & 5.35 \\
\hline finance, services and others & $2,236,210$ & $2,428,524$ & 8.60 & 89,600 & 97,171 & 8.45 & 557,886 & 603,744 & 8.22 \\
\hline
\end{tabular}


Table 6. Simulation of investment impact on employment, wages at TPCT operation phase.

\begin{tabular}{|c|r|r|r|r|r|r|}
\hline \multirow{2}{*}{ sector } & \multicolumn{3}{|c|}{ employment } & \multicolumn{3}{c|}{ wages } \\
\cline { 2 - 6 } & \multicolumn{1}{|c|}{ base } & Simulation & $\pm \%$ & \multicolumn{1}{c|}{ base } & Simulation & $\pm \%$ \\
\hline agriculture & 507,362 & 510,812 & 0.68 & 114,724 & 115,539 & 0.71 \\
\hline mining & 22,352 & 21,800 & -2.47 & 8,234 & 8,032 & -2.45 \\
\hline processed food & 84,700 & 81,430 & -3.86 & 33,860 & 32,539 & -3.90 \\
\hline other chemical products & 60,342 & 61,446 & 1.83 & 21,144 & 21,567 & 2.00 \\
\hline petroleum refineries & 5,138 & 5,354 & 4.20 & 5,250 & 5,468 & 4.16 \\
\hline iron and steel & 24,336 & 25,346 & 4.15 & 13,482 & 14,035 & 4.10 \\
\hline electronics and relatives & 44,300 & 48,198 & 8.80 & 15,924 & 17,190 & 7.95 \\
\hline Precision machinery & 195,082 & 211,508 & 8.42 & 53,994 & 58,606 & 8.54 \\
\hline Other manufacturing & $1,013,622$ & 945,912 & -6.68 & 450,940 & 423,478 & -6.09 \\
\hline construction, civil engineering & 314,886 & 301,471 & -4.26 & 120,834 & 115,638 & -4.30 \\
\hline electricity, gas and water & 26,616 & 27,553 & 3.52 & 25,446 & 26,370 & 3.63 \\
\hline transportation & 249,628 & 269,973 & 8.15 & 125,214 & 135,381 & 8.12 \\
\hline wholesale, retail, and food services & 893,034 & 993,667 & 4.55 & 273,824 & 286,228 & 4.53 \\
\hline finance, services and others & $1,773,856$ & $1,895,542$ & 6.86 & 830,526 & 887,168 & 6.82 \\
\hline
\end{tabular}

Table 7. Simulation of the regional economic impact at TPCT operation phase.

\begin{tabular}{|c|c|c|c|}
\hline \multicolumn{5}{|c|}{ (million NT) } \\
\hline Regional GDP & base & simulation & $\pm \%$ \\
\hline+ consumption & $2,551,468$ & $2,655,568$ & 4.08 \\
\hline+ investment & 972,654 & $1,094,236$ & 12.50 \\
\hline+ government & 566,708 & 595,157 & 5.02 \\
\hline+ export & $1,865,508$ & $2,024,636$ & 8.53 \\
\hline -import & $1,818,958$ & $1,992,850$ & 9.56 \\
\hline total & $4,137,380$ & $4,376,747$ & \\
\hline
\end{tabular}

and peripheral equipment Mfg., logistics and telecommunications), the precision machinery manufacturing industry, and then in the commerce and service industry. Industries subject to the greatest income effect in northern Taiwan are the same as those subject to the employment effect.

\section{CONCLUSIONS}

A regional computable general equilibrium model is constructed and is applied to analyse the economic impact of the establishment of TPCT on the northern region in Taiwan's economy. Construction of the model required the following steps. Reviewing the current literature on regional impact models, describing the model in detail, and collecting and reconciling data to fit the model, and completing the simulation analysis. The limitations to this model concern the assumptions about the functional form of the behavior of economic agents in consumption, production, and so on; additional research is needed to relax these assumptions. Therefore, this study's simulation results are only a first step in policy making.
Further results need more detailed calculations and judgments.

\section{REFERENCES}

1. Adams, P. D. and Parmenter, B. R., "An applied general equilibrium analysis of the economic effects of tourism in a quite small, quite open economy," Applied Economics, Vol. 27, pp. 985-994 (1995).

2. Alavalapati, J., White, W., and Patriquin, M., "Economic impacts of changes in the forestry sector: A case study of the Foothills Region in Alberta," Forestry Chronicle, Vol. 75, pp. 121-127 (1999).

3. Armington, P., "A theory of demand for products distinguished by place of production," IMF Staff Papers, Vol. 16, pp. 159-178 (1969).

4. Augier, P. and Gasiorek, M., "The welfare implications of trade liberalization between the Southern Mediterranean and the EU," Applied Economics, Vol. 35, pp. 1171-1190 (2003).

5. Boyd, R. G., Krutilla, K., and McKinney, J., "The impact of tariff liberalization between the United States and Mexico: An empirical analysis," Applied Economics, Vol. 25, pp. 81-90 (1993).

6. Brook, A., Kendrick, D., and Meeraus, A., GAMS: A User's Guide, The Scientific Press, South San Francisco (1992).

7. Burniaux, J. M., Martin, J. P., Nicoletti, G., and Martins, J. O., "GREEN: A multi-sector, multi-region dynamic general equilibrium model for 
quantifying the costs of cubing $\mathrm{CO} 2$ emissions: a technical manual," Economics Department Working Papers, No. 116, OECD, Paris (1992).

8. Chou, J., Kuo, N. F., and Peng, S. L., "Potential impacts of the SARS outbreak on Taiwan's economy," Asian Economic Papers, Vol. 3, pp. 8495 (2004).

9. Chu, Y. P., "Effects of trade liberalization on Taiwan's economy: A computable general equilibrium model," ISSP Working Paper, Academia Sinica, Taipei, Taiwan (1996).

10. Conrad, K., "An econometric model of production with endogenous improvement in energy efficiency, 1970-1995," Applied Economics, Vol. 32, pp. 1153-1160 (2000)

11. Dervis, K., De Melo, J., and Robinson, S., General Equilibrium Models for Development Policy, Cambridge University Press, Cambridge (1982)

12. Directorate-General of Budget, Accounting, \& Statistics (DGBAS), The Report on the Survey of Family Income and Expenditure in Taiwan Area, Executive Yuan, Taiwan (2004).

13. Directorate-General of Budget, Accounting, \& Statistics (DGBAS), National Income in Taiwan Area, Executive Yuan, Taiwan (2004).

14. Directorate-General of Budget, Accounting, \& Statistics (DGBAS), Input-Output Table, Executive Yuan, Taiwan (2004).

15. Directorate-General of Budget, Accounting, \& Statistics (DGBAS), Year book of Manpower Statistics, Executive Yuan, Taiwan (2004).

16. Directorate-General of Budget, Accounting, \& Statistics (DGBAS), The Trend in Multifactor Productivity, Executive Yuan, Taiwan (2004).

17. Hanson, K. and Rose, A., "Factor productivity and income inequality: A general equilibrium analysis," Applied Economics, Vol. 29, pp. 10611071 (1997)

18. Harrigan, F. and McGregor, P. G., "Neoclassical and Keynesian perspectives on the regional macroeconomy: A computable general equilibrium approach," Journal of Regional Science, Vol. 29, pp. 555-573 (1989).

19. Hoffman, S., Robinson, S., and Subramanian, S., "The role of defense cuts in the California recession: computable general equilibrium models and interstate factor mobility," Journal of Regional Science, Vol. 36, pp. 571-595 (1996).

20. Hosoe, N., "Crop failure, price regulation and emergency imports of Japan's rice sector in 1993," Applied Economics, Vol. 36, pp. 1051-1056 (2004).

21. IMPLAN Group, User's Guide: IMPLANPro Social Accounting and Impact Analysis Software, IMPLAN, Stillwater, MN (2005).

22. Jones, R. and Whalley, J., "A Canadian regionalgeneral equilibrium model and some applications," Journal of Urban Economics, Vol. 25, pp. 368-404 (1989).

23. Koh, Y., "Analysis of Oklahoma's boom and bust economy by means of a CGE model," Unpublished Ph.D. Dissertation, Oklahoma State University, Stillwater, Oklahoma (1991).

24. Lin, S. M., "Fuel taxes in Taiwan: Welfare impacts on regional and socioeconomic groups," Academia Economic Papers, Vol. 26, pp. 71-100 (1998).

25. Liu, C. C. "A study on the construction and application of regional computable general equilibrium model: The case of southern region in Taiwan," Unpublished Ph.D. Dissertation, Department of Resources Engineering, National Cheng Kung University, Tainan, Taiwan (2005).

26. Liu, C. C. "A computable general equilibrium model of the southern region of Taiwan: The impact of the Tainan science-based industria park," Applied Economics, Vol. 38, pp. 1655-1661 (2006).

27. Park, I., Regional Integration Among the ASEAN Nations: A Computable General Equilibrium Model Study, Praeger Publishers, Westport, CT (1995).

28. Partridge, M. D. and Rickman, D., "Regional computable general equilibrium modeling: A survey and critical appraisal," International Regional Science Review, Vol. 21, pp. 205-248 (1998).

29. Patriquin, N., Alavalapati, R. R., Wellstead, M.,Young, M., Adamowicz, L., and White, A., "Estimating impacts of resource management policies in the Foothills Model Forest," Canadian Journal of Forest Research, Vol. 33, pp. 147-155 (2003).

30. Philippidis, G. and Hubbard, L. J., "Modelling hierarchical consumer preferences: An application to global food markets," Applied Economics, Vol. 35, pp. 1679-1687 (2003).

31. Piazolo, D., "Investment behaviour in transition countries and computable general equilibrium models," Applied Economics, Vol. 33, pp. 829837 (2001).

32. Rickman, D. S., "Estimating the impacts of regional business assistance programs: Alternative closures in a computable general equilibrium model," Papers in Regional Science, Vol. 71, pp. 421-435 (1992).

33. Sattar, Z., "Privatizing public enterprises in Bangladesh: A simulation analysis of macroeconomic mpacts," Applied Economics, Vol. 21, pp. 1159-1176 (1989).

34. Schreiner, D. F. and Marcouiller, D. W., Computable General Equilibrium Modeling for Regional Analysis, West Virginia University, Web Book (1999).

35. Schwarm, W. and Cutler, H., "Building small city and town SAM and CGE model," Review of Urban \& Regional Development Studies, Vol. 15, pp. 132-147 (2003).

36. Seung, C. K., Harris, T., and MacDiarmid, T., "Economic impacts of surface water reallocation policies: A comparison of supply determined SAM and CGE models," The Journal of Regional Analysis and Policy, Vol. 27, pp. 55-76 (2000)

37. Seung, C. K. and Kraybill, D. S., "Tax incentives in an economy with public goods," Growth and Change, Vol. 30, pp. 128-147 (1999).

38. Shaffer, R., Community Economics: Economic Structure and Change in Smaller Communities, Iowa State University Press, Iowa (1989).

39. Shoven, J. B. and Whalley, J., Applying General Equilibrium, Cambridge University Press, Cambridge (1992).

40. Sullivan, J., McCollum, W. D., and Alward, S. G., "Regional CGE models based on IMPLAN social Accounts: experiments in Arizona and New Mexio," Paper Presented at the Annual Meetings of the Southern Regional Science Association, Memphis, TN, April 17-19 (1997).

41. Tongzon, J. L., "China's membership in the World Trade Organization (WTO) and the exports of the developing economies of East Asia: A computable general equilibrium approach," Applied Economics, Vol. 33, pp. 1943-1959 (2001).

42. Yang, H. Y. "Carbon-reducing taxes and income inequality: General equilibrium evaluation of alternative energy taxation in Taiwan," Applied Economics, Vol. 32, pp. 1213-1221 (2000).

43. Yang, H. Y., "Carbon emissions control and trade liberalization: Coordinated approaches to Taiwan's trade and tax policy," Energy Policy, Vol. 29, pp. 725-734 (2001). 